proved that ethylene 'puts plants to sleep'. He has shown how certain seeds that remain dormant for many years may be induced to grow if given proper treatments. Low temperatures, chemicals, light and other environmental agencies have been used to break these long rest periods. His work on the physiology of dormancy in seeds has contributed to fundamental knowledge of life processes. The Gold Medal of the American Institute may be awarded either to organizations or to individuals.

WALDEMAR KAEMPFFERT, science editor of the New York Times, and Dr. Raymond L. Ditmars, curator of reptiles and mammals of the New York Zoological Park, have been awarded fellowships of the American Institute for their contributions to science. Mr. Waldemar Kaempffert was awarded the fellowship "for his scholarly interpretation of scientific advances, for his editorial wisdom, for his adroit cultivation of the public mind toward a rational outlook and for his leadership in enforcing their social responsibilities upon scientists". Mr. Kaempffert, who is president of the National Association of Science Writers, has for many years been a leader in the promotion and maintenance of the high standards of science reporting in the United States. He took up his duties as science editor of the New York Times in 1927, leaving in 1928 to become the first director of the Museum of Science and Industry in Chicago. $\mathrm{He}$ is responsible for the real establishment of that great institution for the interpretation of science to the public. Mr. Kaempffert returned to the New York Times in 1931, where his weekly columns on the latest developments of science have become a source of invaluable information to thousands of readers not only on the facts of science but also on its philosophy.

Dr. Raymond L. Ditmars has received the American Institute fellowship "for his thirty-seven years of distinguished service in the care, understanding and interpretation of the reptile world and for his inspiring of youthful spirits with the zeal of the naturalist". Dr. Ditmars is the author of many fascinating volumes on his work with snakes, including "The Making of a Scientist", "The Thrills of a Naturalist's Quest", "Snakes of the World" and "The Forest of Adventure", which latter presents his subject especially for boys and girls. At his laboratory in the New York Zoological Park, Dr. Ditmars is engaged in biochemical research on the subject of snake poisons as a useful substance for the treatment of certain human ailments, including hæmophilia, the reduction of pain, and epilepsy. In announcing these fellowships, Dr. Gerald Wendt, director of the American Institute, explained that they were awarded each year by the Institute to "persons who have done outstanding work in the interpretation of scientific, engineering or industrial work, which promotes with effectiveness the knowledge and general understanding of these arts and sciences. The recognition of these interpreters of science is an important element in the
Institute's programme, which has as its primary purpose the integration of scientific advances with the social structure."

\section{The Soviet North Polar Station}

DURING the last two months, the Soviet observatory placed on a floe near the North Pole in May 1937 has been drifting rapidly southward in the East Greenland current. Fortunately for the safety of Papanin and his three companions, the drift cleared the north-east corner of Greenland and the floe appears to have kept to the outside of the stream of ice down the coast. On February 3, the station was reported to be in lat. $74^{\circ} 8^{\prime} \mathrm{N}$., long. $16^{\circ} 24^{\prime} \mathrm{W}$., which was within about eighty miles of the Norwegian observatory of Myggbukten at the mouth of Franz Josef Fjord in East Greenland. It is reported that although this station is not functioning, it shelters a wintering party of four men provided with dog teams. To try to reach the shore, however, over the drifting and grinding pack would be difficult and hazardous. The floe on which the Soviet party is living has split; the men have lost some of their equipment and are now on a small floe, but they have their tents, instruments, three months' stores and sledges.

RELIEF for the expedition is being hurried forward, but will be impeded by the winter darkness and the difficulty of finding an adequate landing place for aeroplanes. The Times reports that the small wooden survey vessel Murmanets is near Jan Mayen, a distance of less than two hundred miles, and that the Arctic ship Taimyr has left Murmansk with aeroplanes and dog teams. Cinematograph equipment is being taken by the T'aimyr and it is hoped to film the voyage of the vessel, the North Polar station, the removal of Papanin and his companions from the ice-floe and their return home. As the work will have to be done in the darkness of the Polar night, portable lighting equipment to be operated by current from the Taimyr is being taken. In the event of the vessel being unable to approach close enough to the ice-floe, a small portable generator and magnesium flares will be used. The Taimyr has been delayed by heavy weather and the more powerful Murman sailed from Murmansk on February 6. The icebreaker Yermak, with aeroplanes, was to leave Leningrad on February 8 , but has a long journey ahead of her. Aeroplanes are also leaving Green Harbour, Spitsbergen. Prof. O. Schmidt is directing the relief operations. Papanin's message that wireless communication may be interrupted but that there is no immediate danger expresses the daring of these adventurous men. The Norwegian and Danish authorities have offered to assist in the rescue work.

\section{Colour Television at the Dominion Theatre, London}

ON February 4, a surprise item was introduced into the regular programme of the Dominion Picture Theatre, London. At 8 p.m. an experimental demonstration of Baird colour television was effected for 